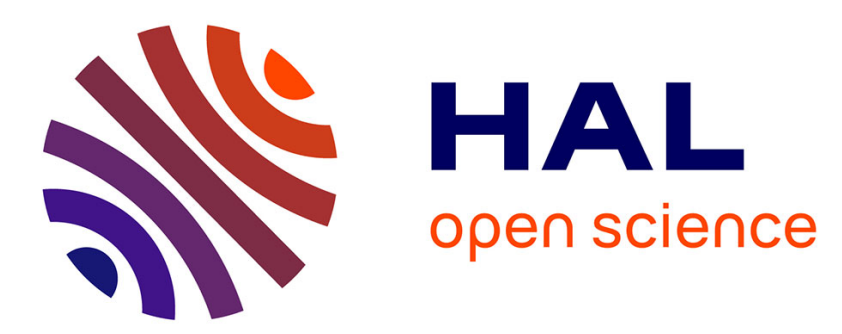

\title{
High Performance Plasma Sputtered PdPt Fuel Cell Electrodes with Ultra Low Loading
}

\author{
Mathieu Mougenot, Amaël Caillard, Pascal Brault, Steve Baranton, \\ Christophe Coutanceau
}

\section{- To cite this version:}

Mathieu Mougenot, Amaël Caillard, Pascal Brault, Steve Baranton, Christophe Coutanceau. High Performance Plasma Sputtered PdPt Fuel Cell Electrodes with Ultra Low Loading. International Journal of Hydrogen Energy, 2011, 36, pp.8429-8434. 10.1016/j.ijhydene.2011.04.080 hal-00598374

\section{HAL Id: hal-00598374 \\ https://hal.science/hal-00598374}

Submitted on 6 Jun 2011

HAL is a multi-disciplinary open access archive for the deposit and dissemination of scientific research documents, whether they are published or not. The documents may come from teaching and research institutions in France or abroad, or from public or private research centers.
L'archive ouverte pluridisciplinaire HAL, est destinée au dépôt et à la diffusion de documents scientifiques de niveau recherche, publiés ou non, émanant des établissements d'enseignement et de recherche français ou étrangers, des laboratoires publics ou privés. 


\title{
High Performance Plasma Sputtered PdPt Fuel Cell Electrodes with Ultra
}

\section{Low Loading}

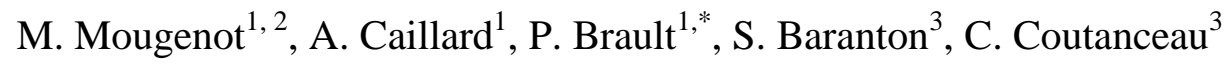 \\ ${ }^{1}$ GREMI, UMR6606 CNRS-Université d'Orléans, BP6744, 45067 Orléans Cedex 2, France. \\ ${ }^{2}$ Agence Innovation M.I.D, 4 Rue Albert Caquot - 28500 Vernouillet - France \\ ${ }^{3}$ LACCO, UMR 6503 CNRS-Université de Poitiers, 40 avenue du Recteur Pineau, 86022 \\ Poitiers, France \\ Received \\ [*] Corresponding author: Pascal.Brault@univ-orleans.fr
}

\begin{abstract}
A PdPt (10 wt\% Pt) catalyst is used to replace platinum at the cathode of a PEMFC MEA whereas pure palladium is used as the anode catalyst. The catalysts are deposited on commercial carbon woven web and carbon paper GDLs by plasma sputtering. The relations between the depth density profiles, the electrode support and the fuel cell performances are discussed. It is shown that the catalyst gradient is an important parameter which can be controlled by the catalyst depth density profile and/or the choice of electrode support. An optimised electrode structure has been obtained, which allows limiting the platinum requirement. Under suitable conditions of a working PEMFC $\left(80^{\circ} \mathrm{C}\right.$ and 3 bar absolute pressure), very high catalysts utilization is obtained at both electrodes, leading to $250 \mathrm{~kW} \mathrm{~g}_{\mathrm{Pt}}{ }^{-1}$ and $12.5 \mathrm{~kW} \mathrm{~g}_{\mathrm{Pd}}{ }^{-1}$ with a monocell fitted with a PdPt (10:1 weight ratio) cathode and a pure Pd anode.
\end{abstract}

Keywords: Catalyst thin film, Low Pt content, Palladium, PEMFC. 


\section{Introduction}

The great potential for the fuel cell technology to overcome the upcoming energy and resources issues in our society, justifies important research investments. Scaling up this technology in a hydrogen economy scenario would require reducing significantly the costs. DOE's objectives to be reached between 2010 and 2015 are clear: the catalyst of a fuel cell can cost no more than $5 / 3 €$ per kilowatt [1]. If the catalyst is platinum $\left(\sim 40 € \mathrm{~g}^{-1}\right)$, as commonly used at the moment in 2010, the fuel cell performance to achieve is ca. $10 \mathrm{~kW} \mathrm{~g}_{\mathrm{Pt}}{ }^{-1}$. Commercial fuel cells currently used in cars have a resource efficiency of 1 or 2 $\mathrm{kW} \mathrm{g}_{\mathrm{Pt}}{ }^{-1}$. The high amount of platinum makes commercial fuel cells reliable but the resource efficiency is far too low to provide a scalable transport solution. One of the solutions is to replace platinum by a cheaper catalytic material. Palladium appears to be a serious candidate for being almost twice cheaper than platinum, and because it has some catalytic activity either for the hydrogen oxidation or for the oxygen reduction. Indeed, Y.-N. Wu et al. have recently shown, by comparing $\mathrm{Pd} / \mathrm{C}, \mathrm{PdPt} / \mathrm{C}$, a dual layer of $\mathrm{PdPt}$ on $\mathrm{Pt} / \mathrm{C}$ and $\mathrm{Pt} / \mathrm{C}$ catalysts activities by cyclic voltammetry, that cathode platinum can efficiently be replaced by a PdPt alloy or a dual layer of PdPt on Pt/C [2]. A. C. Garcia and al. have studied the tolerance of pure Pt, Pd and a PdPt alloy toward CO poisoning and have shown that there are less $\mathrm{Pd}-\mathrm{CO}$ interactions in a $\mathrm{PdPt}$ catalyst than pure Pd and Pt [3]. Y.-H. Cho et al and F. Alcaide et al. have demonstrated that the anodic platinum can efficiently be replaced by a PdPt 
alloy with $5 \%$ at. of platinum $[4,5]$. Keeping a platinum loaded cathode, the performance obtained with the PdPt anode was the same as the one obtained with platinum only (Anode: $0.2 \mathrm{mg}_{\mathrm{Pt}} \mathrm{cm}^{-2}$; Cathode: $0.2 \mathrm{mg}_{\mathrm{Pt}} \mathrm{cm}^{-2}$ ), showing also that a very small amount of platinum is required at the anode. Moreover, we have recently developed fuel cell electrodes loaded with a very small amount of platinum deposited by magnetron sputtering at the anode and at the cathode (Anode: $0.01 \mathrm{mg}_{\mathrm{Pt}} \mathrm{cm}^{-2}$; Cathode: $0.01 \mathrm{mg}_{\mathrm{Pt}} \mathrm{cm}^{-2}$ ). This deposition technique is largely used in the industry and in the research and development of fuel cells [68]. It has the advantage of allowing the deposition of very small quantities of material and the optimisation of its nanostructure $[9,10]$. So far, these MEAs are demonstrating the world's highest fuel cell performance, with a total platinum (anode + cathode) utilization, of $20 \mathrm{~kW} \cdot \mathrm{g}_{\mathrm{Pt}}{ }^{-1}[11,12]$. Analysis by Rutherford Backscattering Spectroscopy (RBS) has shown that the platinum density depth profile inside the diffusion layer is a key parameter to explain such a high efficiency [11]. E. Billy et al. have studied the impact of low catalyst loadings in PEMFC and have concluded that the MEA performances is more influenced by the catalyst nanostructure, especially the particles size, than the actual mass of platinum in the electrodes [13].

We propose a further development of the low catalyst loading concept in combining low catalyst loadings and the replacement of platinum by a $\mathrm{PdPt}$ catalyst with only $10 \mathrm{wt} \%$ of platinum. Catalysts are deposited on different backing layers by plasma sputtering and the catalyst density depth profiles are 
determined by RBS. Several MEAs are tested with a home made single cell testing station. All MEAs include a pure palladium loaded anode which can offer comparable performance as platinum loaded anodes [14]. PdPt cathodes of increasing loadings are compared.

\section{Experimental}

The plasma chamber has been previously detailed elsewhere [15]. Briefly, a cylindrical stainless steel low pressure TCP sputtering reactor (height $=260 \mathrm{~mm}$, diameter $=210 \mathrm{~mm}$ ) is used for the deposition of pure Palladium (99.999) or codeposition of palladium and platinum with a single PdPt target with $10 \%$ wt of platinum. The metal target, positioned at middle height, is $45^{\circ}$ tilted in front of a plane rotating substrate holder. An argon plasma is created in the chamber by an external planar RF antenna (13.56 MHz) positioned on the top glass window. For Pd deposition and PdPt co-deposition, the sputtering conditions remained identical. The target is polarized at $-200 \mathrm{~V}$ and the RF power supply is adjusted between $135 \mathrm{~W}$ and $170 \mathrm{~W}$ in order to keep a cathode current of $40 \mathrm{~mA}$. The deposition conditions remained the same: $5 \mu$ bar, $5 \mathrm{sccm}$ (Ar). After $40 \mathrm{~min}$ of pure palladium deposition, the palladium anodes are loaded with $74 \mu \mathrm{g} \mathrm{cm}^{-2}$. The PdPt deposition time was varied in order to change the PdPt cathode loadings. All prepared catalysts are deposited on gas diffusion layers (E-TEK LT1200-W ELAT $^{\circledR}$ of $74 \%$ porosity for woven web gas diffusion Layer or SIGRACET GDL $10 \mathrm{BB}$ of $84 \%$ porosity for carbon paper gas diffusion layer). For all electrodes, Table 1 gives the palladium, platinum and the total weight 
composition and the weight ratio of platinum and the corresponding gas diffusion layer (GDL) support. The Rutherford Backscattering Spectroscopy (RBS) has been used to measure the total metal loadings. For MEA fabrication, a membrane (a Nafion ${ }^{\circledR} 212$ membrane, purchased from Quintech, Germany, noted further in the text N212) was sandwiched without pre-humidification between two electrodes (an anode and a cathode of $25 \mathrm{~cm}^{2}$ geometric surface each) used as prepared by plasma sputtering (without Nafion ${ }^{\circledR}$ solution addition). The MEAs is mechanically pressed at $2 \mathrm{Nm}$ torque (without hot pressing). Under our testing conditions, the pressure is manually regulated with the output valves and both the hydrogen and oxygen humidifiers are at room temperature.

\section{Results and Discussion}

A RBS spectrum obtained from one of the co-sputtered PdPt catalyst is displayed in Figure 1. Both the platinum and palladium peaks display an asymmetric shape as previously observed for pure Pt deposition on carbon woven web GDLs [16]. The asymmetric shape of the Pd and Pt peaks results from the diffusion from the surface of the metallic atoms inside the porous GDL. The platinum peak tail overlaps with the palladium peak front. The spectrum decomposition is possible when overlapping remains small. This was always the case in our conditions. The asymmetric shape is due to atomic diffusion of the metal atoms into the GDL. After simulating the RBS spectra with the software SIMNRA [17], it is possible to calculate the palladium density depth profile. 
The obtained palladium density profiles for the PdPt/C catalyst are displayed in Figure 2. The density depth profiles show that when the catalyst loading is increased, the density at the surface of the GDL, in contact with the membrane in a fuel cell MEA, does not increase so much. On the other hand, the in-depth density increases significantly when the catalyst loading increases. In previous works on PtRu sputtered catalysts for DMFC application, we showed that cosputtering of $\mathrm{Pt}(\mathrm{fcc})$ and $\mathrm{Ru}(\mathrm{hcp}$ ) leads to alloys with Pt fcc structure. In the present case, both metals having a fcc structure are co-sputtered; it is then reasonable to propose that $\mathrm{Pt}$ is doped into the Pd lattice.

Four MEAs have been built with our set of electrodes; kind of GDL, metal loadings, maximum cell power density and power density achieved at $0.5 \mathrm{~V}$ are summarized in Table 1. The fuel cell performances obtained with the Pd-N212PdPt MEAs are displayed and discussed below. Under each testing conditions, the testing parameters were tuned in order to get the more stable responses and the highest cell performances. The polarisation curves are discussed considering that the main limiting processes are reaction kinetics (charge transfer) in the low current density region, ohmic drop in the intermediate current density region and mass transport for high current density [18-20]. Figure 3 displays the voltage and power density vs current density curves, $\mathrm{V}-\mathrm{j}$ and $\mathrm{P}-\mathrm{j}$, obtained with a Nafion ${ }^{\circledR} 212$ membrane sandwiched between a pure palladium anode $\left(74 \mu \mathrm{g}_{\mathrm{Pd}}\right.$ $\left.\mathrm{cm}^{-2}\right)$ and a PdPt cathode $\left(160 \mu \mathrm{g}_{\mathrm{Pd}} \mathrm{cm}^{-2}+14 \mu \mathrm{g}_{\mathrm{Pt}} \mathrm{cm}^{-2}\right)$. The cell temperature has been increased from $70^{\circ} \mathrm{C}$ to $80^{\circ} \mathrm{C}$ keeping a constant oxygen and hydrogen 
pressure of 2 bars. Higher cell performances in terms of power densities were achieved at $75{ }^{\circ} \mathrm{C}$. Although the MEA's cathode is highly loaded with palladium, the maximum achieved current density (ca. $0.4 \mathrm{~A} \mathrm{~cm}^{-2}$ at ca. $0.1 \mathrm{~V}$ ) and power density (ca. $90 \mathrm{~mW} \mathrm{~cm}^{-2}$ at ca. $0.36 \mathrm{~V}$ and ca. $50 \mathrm{~mW} \mathrm{~cm}$ at ca. 0.65 V) are very low compared to classic commercial performances (about $800 \mathrm{~mW}$ $\mathrm{cm}^{-2}$ at ca. $0.65 \mathrm{~V} \mathrm{[21]).} \mathrm{Previous} \mathrm{observations} \mathrm{[22]} \mathrm{have} \mathrm{shown} \mathrm{that} \mathrm{increasing}$ the metal loading leads to a percolated and a denser thin film on the surface of the porous carbon substrate decreasing the active surface area. The comparison of the depth density profiles displayed in Figure 2 shows that the MEA-A's cathode has the highest palladium density over a depth of $600 \mathrm{~nm}$. The gas diffusion layer is saturated with palladium, at the surface and/or in depth, causing a gas feeding drop and limiting the number of active sites. According to the different palladium density profiles, decreasing the PdPt cathode loading from $174 \mu \mathrm{g} \mathrm{cm}^{-2}$ to $85 \mu \mathrm{g} \mathrm{cm} \mathrm{c}^{-2}$ leads to decrease the palladium density at the surface and in depth. The voltage/power density vs current density curves are displayed in Figure 4. At $70^{\circ} \mathrm{C}$, when the $\mathrm{H}_{2}$ and $\mathrm{O}_{2}$ pressures are increased from 1 bar to 3 bars, the MEA-B maximum performance at ca. $0.45 \mathrm{~V}$ increases: 100 $\mathrm{mW} \mathrm{cm}{ }^{-2}$ at 1 bar, $180 \mathrm{~mW} \mathrm{~cm}^{-2}$ at 2 bar and $250 \mathrm{~mW} \mathrm{~cm}^{-2}$ at 3 bar. Compared to the MEA-A, the maximum power density is much higher even though the cathode catalyst loading is 1.6 times lower. The expected increase of the active surface area due to the reduction of the catalyst loading has a significant impact on the performance. Increasing the cell temperature from $70^{\circ} \mathrm{C}$ to $80^{\circ} \mathrm{C}$ at 3 bar 
increases the maximum current density from $1 \mathrm{~A} \mathrm{~cm}^{-2}$ to $1.2 \mathrm{~A} \mathrm{~cm}^{-2}$. From $70^{\circ} \mathrm{C}$ to $80^{\circ} \mathrm{C}$, the maximum power density (at $0.6 \mathrm{~A} \mathrm{~cm}^{-2}$ ) remains the same and so the performance at low current densities (below $0.6 \mathrm{~A} \mathrm{~cm}^{-2}$ ). Increasing the temperature can lead to a better water removal [23] from the GDL and the active layer, allowing better gas (oxygen) accessibility to cathode active sites, which has a great influence on the high current density domain. The catalyst loading of the MEA-C is lower (Figure 5). The MEA-C provides a maximum power density at ca. $0.43 \mathrm{~V}$ of $280 \mathrm{~mW} \mathrm{~cm}$ at a pressure of 3 bars and a cell temperature of $70^{\circ} \mathrm{C}$. Increasing the gas pressure increases the performance. With a cathode catalyst loading almost twice lower than that of MEA-B, the MEA-C performance is better at both low and high pressures. Among the three first MEAs, the MEA-C leads to the best performance. So, the sputtered catalyst loading (40 $\mu \mathrm{g}_{\mathrm{Pd}} / \mathrm{cm}^{2}$ and $4 \mu \mathrm{g}_{\mathrm{Pt}} / \mathrm{cm}^{2}$ ) and the density profile (Figure 2) obtained in this case seems to be optimized, considering that the palladium atomic density at the surface (in contact with the membrane in the MEA) is similar to the one of the MEA-B's cathode whereas the palladium atomic density in depth is lower. Thus, with a similar surface directly in contact with the membrane, a higher porosity in depth can improve the water management in the electrode and so the performance.

The commercial GDLs based on carbon paper display a higher porosity than carbon woven web GDLs. Based on the previous observations, i. e. a high improvement of the PEMFC performance when increasing the porosity in depth, 
two carbon paper GDLs have been coated by plasma sputtering with $10 \mu \mathrm{g}_{\mathrm{Pd}} \mathrm{cm}^{-}$ ${ }^{2}$ for the anode and $10 \mu \mathrm{g}_{\mathrm{Pd}} \mathrm{cm}^{-2}$ plus $1 \mu \mathrm{g}_{\mathrm{Pt}} \mathrm{cm}^{-2}$ for the cathode. The MEA-D, involving these two electrodes and a Nafion ${ }^{\circledR} 212$ membrane, has been tested (Figure 6). The MEA-D provides a maximum power density of $120 \mathrm{~mW} \mathrm{~cm}^{-2}$ (at ca. $0.32 \mathrm{~V}$ ) at 2 bars and $50{ }^{\circ} \mathrm{C}$ and $200 \mathrm{~mW} \mathrm{~cm}^{-2}$ (at ca. $0.34 \mathrm{~V}$ ) at 3 bars and $70^{\circ} \mathrm{C}$. With a low catalyst loading, less dense active layer is obtained and the accessibility to active sites will likely be higher, so that the expected good catalyst dispersion at the interface electrode-membrane justifies the power density measured at high pressure (3 bars). However, the power density at lower pressure ( 2 bars) is lower than that obtained with the MEA-C because of the low catalyst loading. Indeed, at low pressure ( 2 bars) there is less reactive molecules in a given volume fraction close to the catalytic sites in the catalytic layer than at high pressure (3 bars), so that mass transport limitation are higher than for higher pressures. A thicker active layer is required to keep the same power density than at a higher pressure. When the cell temperature is increased to $80^{\circ} \mathrm{C}$, the power density increases for both low and high current densities domains and reaches $250 \mathrm{~mW} \mathrm{~cm}{ }^{-2}$ at ca. $0.36 \mathrm{~V}$. It shows that the temperature increase improves the water management in the MEA-D, as expected, and also improves the catalysis of reactions for both electrode catalysts. At 3 bars and 80 ${ }^{\circ} \mathrm{C}$, the MEA-D provides the same power density as the MEA-B and can supply a higher current density $\left(1.1 \mathrm{~A} \mathrm{~cm}^{-2}\right)$ but with almost 8 times less catalysts. Among the 4 tested MEAs, the MEA-D, using carbon paper GDLs instead of 
carbon woven web GDLs, provides the highest power density at high current density $\left(230 \mathrm{~mW} \mathrm{~cm}{ }^{-2}, 1.1 \mathrm{~A} \mathrm{~cm}^{-2} ; 0.2 \mathrm{~V}\right)$. It shows that the porosity gradient is an important parameter of optimisation and that it can be controlled by the catalyst depth density profile and/or the choice of electrode support.

\section{Conclusion}

A PdPt (10:1 weight ratio) catalyst has been chosen to replace platinum at the cathode of PEMFC MEAs and pure palladium was used as the anode catalyst. The catalysts were deposited on commercial carbon woven web and carbon paper GDLs by plasma sputtering. The palladium depth density profiles inside the GDLs were calculated from RBS measurements. The relations between the depth density profiles, the electrode support and the fuel cell performances have been discussed. After this study, an optimised electrode structure has been obtained, limiting the platinum requirement. With $0.25 \mathrm{~W} \mathrm{~cm}^{-2}$ produced from a total catalyst loading of only $0.02 \mathrm{mg}_{\mathrm{Pd}} \mathrm{cm}^{-2}$ and $0.001 \mathrm{mg}_{\mathrm{Pt}} \mathrm{cm}^{-2}$ deposited on carbon paper electrodes by plasma sputtering, we have developed a very

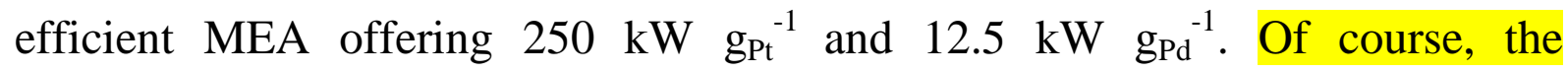
performances of such MEAs have to be checked under air atmosphere to be closer to transportation applications; however, even by dividing the performance by a factor 5, they still appear very high. The durability of such MEA has also to be studied and, if necessary, improved to dispose of a system for which the platinum need is no longer limiting for the development at world scale of the PEMFC technology. 


\section{Acknowledgements}

"Agence Innovation Made In Dreux" is gratefully acknowledged for granting a fellowship (MM). CNRS is acknowledged for granting the Programme Interdisciplinaire "Anergie "AMELI-0Pt" and "AMEPlas". 


\section{References}

[1] http://hydrogendoedev.nrel.gov/pdfs/progress10/v_a_3_sinha.pdf; april $1^{\text {st }}$, 2011.

[2] Y.-N. Wu, S.-J. Liao, Z.-X. Liang, L.-J. Yang, R.-F. Wang, Highperformance core-shell PdPt@Pt/C catalysts via decorating PdPt alloy cores with Pt, J. Power Sources 2009; 194:805-810.

[3] A. C. Garcia, V. A. Paganin, E. A. Ticianelli, CO tolerance of PdPt/C and PdPtRu/C anodes for PEMFC, Electrochemica Acta 2008;53:4309-4315.

[4] Y.-H. Cho, B. Choi, Y.-H. Cho, H.-S. Park, Y.-E. Sung, Pd-based PdPt (19: 1)/C electrocatalyst as an electrode in PEM fuel cell, Electrochem. Comm. $2007 ; 9: 378-381$.

[5] F. Alcaide, G. Alvarez, P. L. Cabot, O. Miguel, A. Querejeta, Performance of carbon-supported PtPd as catalyst for hydrogen oxidation in the anodes of proton exchange membrane fuel cells, Int. J. Hydrogen Energy 2010;35: 1163411641.

[6] P. Brault, A. Caillard, A.-L. Thomann, J. Mathias, C. Charles, R.W. Boswell, S. Escribano, J. Durand,T. Sauvage, Plasma sputtering deposition of platinum into porous fuel cell electrodes, J. Phys. D: Appl. Phys. 2004;37:3419-3423.

[7] A. Caillard, C. Charles, R. Boswell, P. Brault, C. Coutanceau, Plasma based platinum nanoaggregates deposited on carbon nanofibers improve fuel cell efficiency, Appl. Phys. Lett. 2007;90:223119. 
[8] A. Chen, P. Holt-Hindle, Platinum-Based Nanostructured Materials:

Synthesis, Properties, and Applications, Chem. Rev. 2010;110:3767-3804.

[9] P. Andreazza, C. Andreazza-Vignolle, J.P. Rozenbaum, L. Thomann, P. Brault, Nucleation and initial growth of platinum islands by plasma sputter deposition, Surf. Coatings Technol. 2002;151:122-127.

[10] A. L Thomann , P Brault, J P Rozenbaum , C Andreazza-Vignolle , P Andreazza , H Estrade-Szwarckopf , B Rousseau , D Babonneau and G Blondiaux, Chemical and morphological characterization of Pd aggregates grown by plasma sputter deposition, J. Phys. D: Appl. Phys. 1997;30 :31973202.

[11] M. Cavarroc, A. Ennadjaoui, M. Mougenot, P. Brault, R. Escalier, Y. Tessier, J. Durand, S. Roualdès, T. Sauvage, C. Coutanceau, Performance of plasma sputtered fuel cell electrodes with ultra-low Pt loadings, Electrochem. Comm. 2009;11:859-861.

[12] S. Martin, P. L. Garcia-Ybarra, J. L. Castillo, High platinum utilization in ultra-low Pt loaded PEM fuel cell cathodes prepared by electrospraying, Int. J. Hydrogen Energy 2010;35:10446-10451.

[13] E. Billy, F. Maillard, A. Morin, L. Guetaz, F. Emieux, C. Thurier, P. Doppelt, S. Donet, S. Mailley, Impact of ultra-low Pt loadings on the performance of anode/cathode in a proton-exchange membrane fuel cell, J. Power Sources 2010;195:2737-2746. 
[14] S. A. Grigoriev, E. K. Lyutikova, S. Martemianov, V. N. Fateev, On the possibility of replacement of Pt by $P d$ in a hydrogen electrode of PEM fuel cells, Int. J. Hyrdogen Energy 2007;32:4438-4442.

[15] A. Caillard C. Coutanceau, P. Brault, J. Mathias, J.-M. Léger, Structure of $P t / C$ and $P t R u / C$ catalytic layers prepared by plasma sputtering and electric performance in direct methanol fuel cells (DMFC), J. Power Sources 2006;162:66-73.

[16] P. Brault, C. Josserand, Jean-Marc Bauchire, A. Caillard, C. Charles, R. Boswell, Anomalous diffusion mediated by atom deposition into a porous substrate, Phys. Rev. Lett. 2009 ; 102: 045901.

[17] M. Mayer, SIMNRA, a Simulation Program for the Analysis of NRA, RBS and ERDA, Proceedings of the 15th International Conference on the Application of Accelerators in Research and Industry, J. L. Duggan and I.L. Morgan (eds.), American Institute of Physics Conference Proceedings 475, p. 541 (1999)

[18] T. R. Ralph, G. A. Hards, J. E. Keating, S. A. Campbell, D. P. Wilkinson, M. Davis, J. St-Pierre, M. C. Johnson, Low Cost Electrodes for Proton Exchange Membrane Fuel Cells, J. Electrochem. Soc. 1997;144:3845-3857.

[19] H. A. Gasteiger, J. E. Panels, S. G. Yan, Dependence of PEM fuel cell performance on catalyst loading, J. Power Sources 2004;127:162-171.

[20] H. A. Gasteiger, S. S. Kocha, B. Sompalli, F. T. Wagner, Activity benchmarks and requirements for Pt, Pt-alloy, and non-Pt oxygen reduction catalysts for PEMFCs, Appl. Catal. B 2005;56:9-35. 
[21] A. J.-J. Kadjo, P. Brault, A. Caillard, C. Coutanceau, J.-P. Garnier, S. Martemianov, Improvement of proton exchange membrane fuel cell electrical performance by optimization of operating parameters and electrodes preparation, J. Power Sources 2007; 172: 613-622.

[22] A. Caillard, C. Charles, D. Ramdutt, R. Boswell, P. Brault, Effect of Nafion and platinum content in a catalyst layer processed in a radio frequency helicon plasma system, J. Phys. D: Appl. Phys. 2009;42:045207.

[23] W. He, G. Lin, and T. Van Nguyen, Diagnostic tool to detect electrode flooding in proton exchange membrane fuel cells, AIChE Journal, 2003; 49:3221-3228. 
Table Caption

Table 1 Description of the 4 Pd-N212-PdPt MEAs based on sputtered catalyst

\begin{tabular}{|c|c|c|c|c|c|c|c|}
\hline MEA & GDL & $\begin{array}{c}\text { Anode loading } / \mu \mathrm{g} \\
\mathrm{cm}^{-2}\end{array}$ & \multicolumn{3}{|c|}{ Cathode loading } & $\mathrm{P}_{\max } @ 0.5 \mathrm{~V}$ & $\mathrm{P}_{\max }$ \\
& & $\mathrm{Pd}$ & $\mathrm{Pt}$ & $\mathrm{Pd}$ & $\mathrm{Total}$ & $\mathrm{T}=80^{\circ} \mathrm{C}$ & $\mathrm{T}=80^{\circ} \mathrm{C}$ \\
\cline { 3 - 8 } & & 74 & 14 & 160 & 174 & 65 & 75 \\
\hline MEA-A & Woven web & 74 & 8 & 77 & 85 & 250 & 250 \\
\hline MEA-B & Woven web & 74 & 4 & 40 & 44 & 270 & 245 \\
\hline MEA-C & Woven web & 10 & 1 & 10 & 11 & 220 & 260 \\
\hline MEA-D & Carbon paper & $10 \mathrm{~mW}^{-2}$ & \\
\hline
\end{tabular}




\section{Figure Caption}

Figure 1 RBS spectrum obtained from a co-sputtered PdPt catalyst deposited on commercial carbon woven web GDL.

Figure 2 Palladium density depth profiles calculated from the Rutherford Backscattering Spectroscopy of plasma sputtered PdPt catalysts on commercial GDL.

Figure 3 Performance $E-j$ and $P-j$ curves obtained with the MEA-A, including a pure palladium anode loaded with $74 \mu \mathrm{g}_{\mathrm{Pd}} \mathrm{cm}^{-2}$ and a PdPt cathode loaded with $160 \mu \mathrm{g}_{\mathrm{Pd}}$ $\mathrm{cm}^{-2}$ and $14 \mu \mathrm{g}_{\mathrm{Pt}} \mathrm{cm}^{-2}$, both mechanically pressed against a Nafion212 membrane. (Testing conditions: $\mathrm{f}_{\mathrm{O}_{2}}=350 \mathrm{sccm}, \mathrm{f}_{\mathrm{H}_{2}}=100 \mathrm{sccm}, \mathrm{P}_{\mathrm{O}_{2}}=\mathrm{P}_{\mathrm{H}_{2}}=2$ bars abs, $\mathrm{T}_{\mathrm{O}_{2}}=\mathrm{T}_{\mathrm{H}_{2}}$ $\left.=\mathrm{T}_{\mathrm{amb}}\right)$.

Figure 4 Performance $E-j$ and $P-j$ curves obtained with the MEA-B, including a pure palladium anode loaded with $74 \mu \mathrm{g}_{\mathrm{Pd}} \mathrm{cm}^{-2}$ and a PdPt cathode loaded with $77 \mu \mathrm{g}_{\mathrm{Pd}} \mathrm{cm}^{-}$ 2 and $9 \mu \mathrm{g}_{\mathrm{Pt}} \mathrm{cm}^{-2}$, both mechanically pressed against a Nafion 212 membrane.

Testing conditions (i): $\mathrm{P}_{\mathrm{O}_{2}}=\mathrm{P}_{\mathrm{H}_{2}}$, at 1 bar abs $\left(\mathrm{f}_{\mathrm{O}_{2}}=150 \mathrm{sccm}, \mathrm{f}_{\mathrm{H}_{2}}=100 \mathrm{sccm}, \mathrm{T}_{\text {cell }}=\right.$ $\left.40^{\circ} \mathrm{C}\right)$, at 2 bar abs $\left(\mathrm{f}_{\mathrm{O}_{2}}=380 \mathrm{sccm}, \mathrm{f}_{\mathrm{H}_{2}}=215 \mathrm{sccm}, \mathrm{T}_{\text {cell }}=60^{\circ} \mathrm{C}\right)$, at 3 bar abs $\left(\mathrm{f}_{\mathrm{O}_{2}}=\right.$ $\left.700 \mathrm{sccm}, \mathrm{f}_{\mathrm{H}_{2}}=325 \mathrm{sccm}, \mathrm{T}_{\text {cell }}=70^{\circ} \mathrm{C}\right), \mathrm{T}_{\mathrm{O}_{2}}=\mathrm{T}_{\mathrm{H}_{2}}=\mathrm{T}_{\mathrm{amb}}$.

Testing conditions (ii): $\mathrm{P}_{\mathrm{O}_{2}}=\mathrm{P}_{\mathrm{H}_{2}}=3 \mathrm{bar}, \mathrm{f}_{\mathrm{O}_{2}}=700 \mathrm{sccm}, \mathrm{f}_{\mathrm{H}_{2}}=325 \mathrm{sccm}\left(\mathrm{T}_{\text {cell }}=\right.$ $\left.70^{\circ} \mathrm{C}\right)$ or $235 \mathrm{sccm}\left(\mathrm{T}_{\text {cell }}=80^{\circ} \mathrm{C}\right), \mathrm{T}_{\mathrm{O}_{2}}=\mathrm{T}_{\mathrm{H}_{2}}=\mathrm{T}_{\mathrm{amb}}$.

Figure 5 Performance $E-j$ and $P-j$ curves obtained with the MEA-C, including a pure palladium anode loaded with $74 \mu \mathrm{g}_{\mathrm{Pd}} \mathrm{cm}^{-2}$ and a PdPt cathode loaded with $40 \mu \mathrm{g}_{\mathrm{Pd}} \mathrm{cm}^{-}$ 2 and $4 \mu \mathrm{g}_{\mathrm{Pt}} \mathrm{cm}^{-2}$, both mechanically pressed against a Nafion212 membrane. 
Testing conditions: $\mathrm{P}_{\mathrm{O}_{2}}=\mathrm{P}_{\mathrm{H}_{2}}$, at 1 bar abs $\left(\mathrm{f}_{\mathrm{O}_{2}}=200 \mathrm{sccm}, \mathrm{f}_{\mathrm{H}_{2}}=155 \mathrm{sccm}, \mathrm{T}_{\text {cell }}=\right.$ $\left.60^{\circ} \mathrm{C}\right)$, at 2 bar abs $\left(\mathrm{f}_{\mathrm{O}_{2}}=380 \mathrm{sccm}, \mathrm{f}_{\mathrm{H}_{2}}=215 \mathrm{sccm}, \mathrm{T}_{\text {cell }}=60^{\circ} \mathrm{C}\right)$, at 3 bar abs $\left(\mathrm{f}_{\mathrm{O}_{2}}=\right.$ $\left.770 \mathrm{sccm}, \mathrm{f}_{\mathrm{H}_{2}}=325 \mathrm{sccm}, \mathrm{T}_{\text {cell }}=70^{\circ} \mathrm{C}\right), \mathrm{T}_{\mathrm{O}_{2}}=\mathrm{T}_{\mathrm{H}_{2}}=\mathrm{T}_{\mathrm{amb}}$.

Figure 6 Performance E-j and $P-j$ curves obtained with the MEA-D, including a pure palladium anode loaded with $10 \mu \mathrm{g}_{\mathrm{Pd}} \mathrm{cm}^{-2}$ and a PdPt cathode loaded with $10 \mu \mathrm{g}_{\mathrm{Pd}} \mathrm{cm}^{-}$ 2 and $1 \mu \mathrm{g}_{\mathrm{Pt}} \mathrm{cm}^{-2}$, both mechanically pressed against a Nafion 212 membrane.

Testing conditions (i): $\mathrm{P}_{\mathrm{O}_{2}}=\mathrm{P}_{\mathrm{H}_{2}}$, at 2 bar abs $\left(\mathrm{f}_{\mathrm{O}_{2}}=400 \mathrm{sccm}, \mathrm{f}_{\mathrm{H}_{2}}=200 \mathrm{sccm}, \mathrm{T}_{\text {cell }}=\right.$ $\left.50^{\circ} \mathrm{C}\right)$, at 3 bar abs $\left(\mathrm{f}_{\mathrm{O}_{2}}=750 \mathrm{sccm}, \mathrm{f}_{\mathrm{H}_{2}}=330 \mathrm{sccm}, \mathrm{T}_{\text {cell }}=70^{\circ} \mathrm{C}\right), \mathrm{T}_{\mathrm{O}_{2}}=\mathrm{T}_{\mathrm{H}_{2}}=\mathrm{T}_{\mathrm{amb}}$.

Testing conditions (ii): $\mathrm{P}_{\mathrm{O}_{2}}=\mathrm{P}_{\mathrm{H}_{2}}=3$ bar, $\mathrm{f}_{\mathrm{O}_{2}}=750 \mathrm{sccm}, \mathrm{f}_{\mathrm{H}_{2}}=330 \mathrm{sccm}, \mathrm{T}_{\mathrm{O}_{2}}=\mathrm{T}_{\mathrm{H}_{2}}=$ $\mathrm{T}_{\mathrm{amb}}$. 


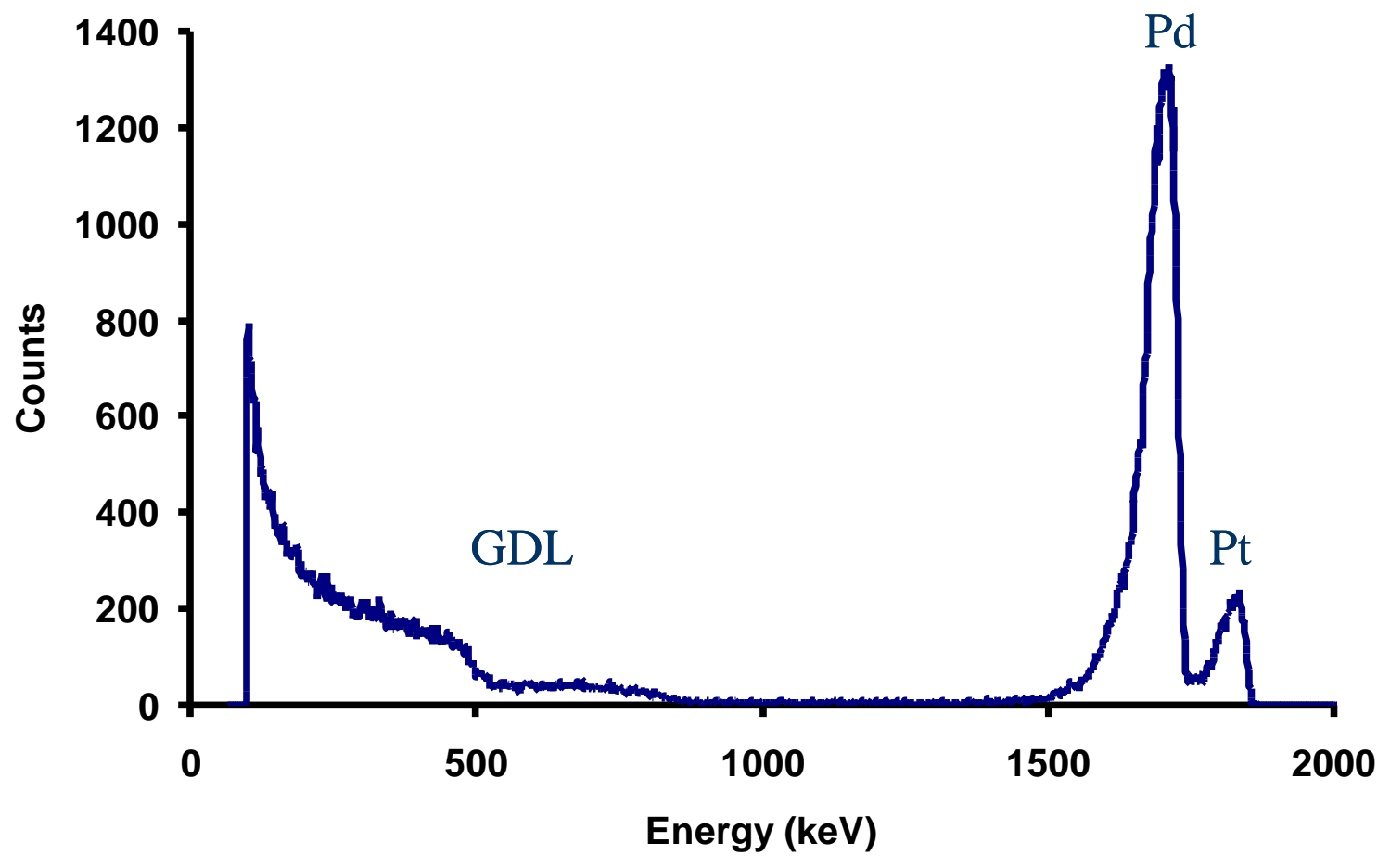

Fig. 1 


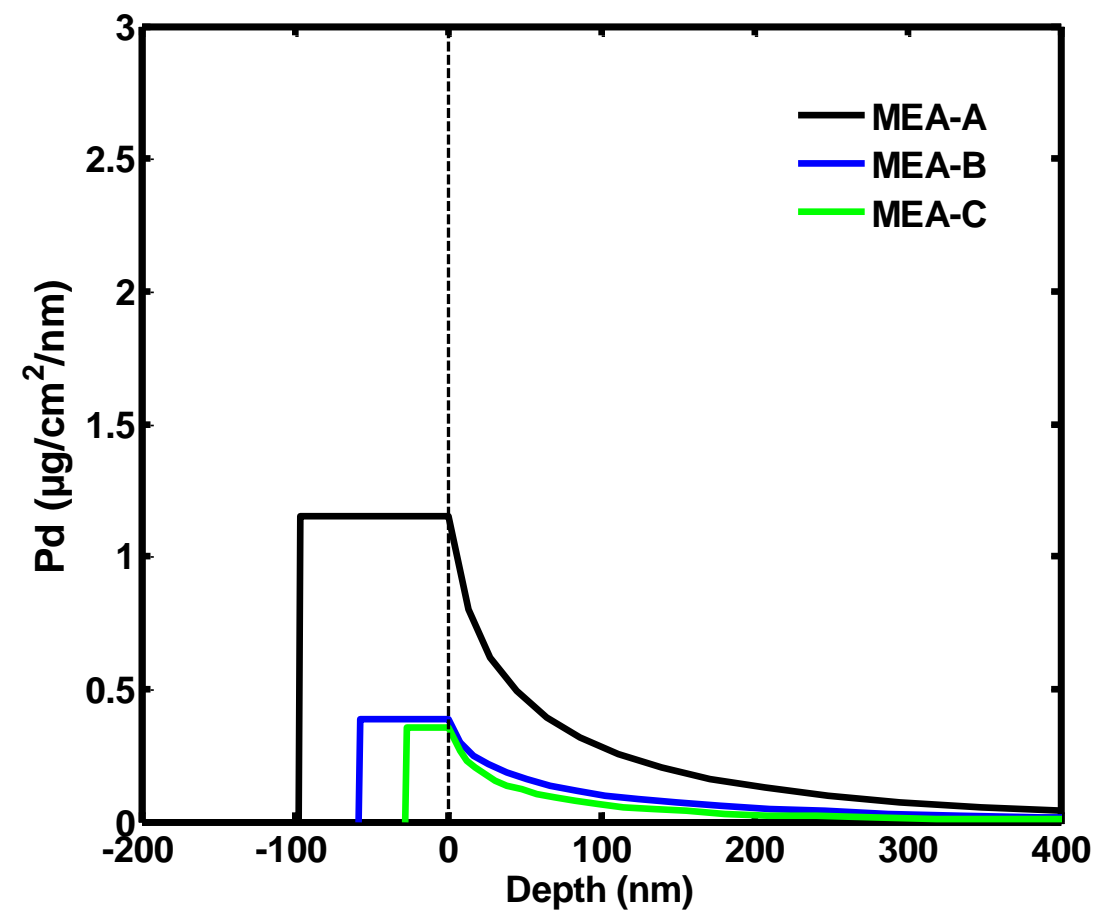

Fig. 2 
MEA-A

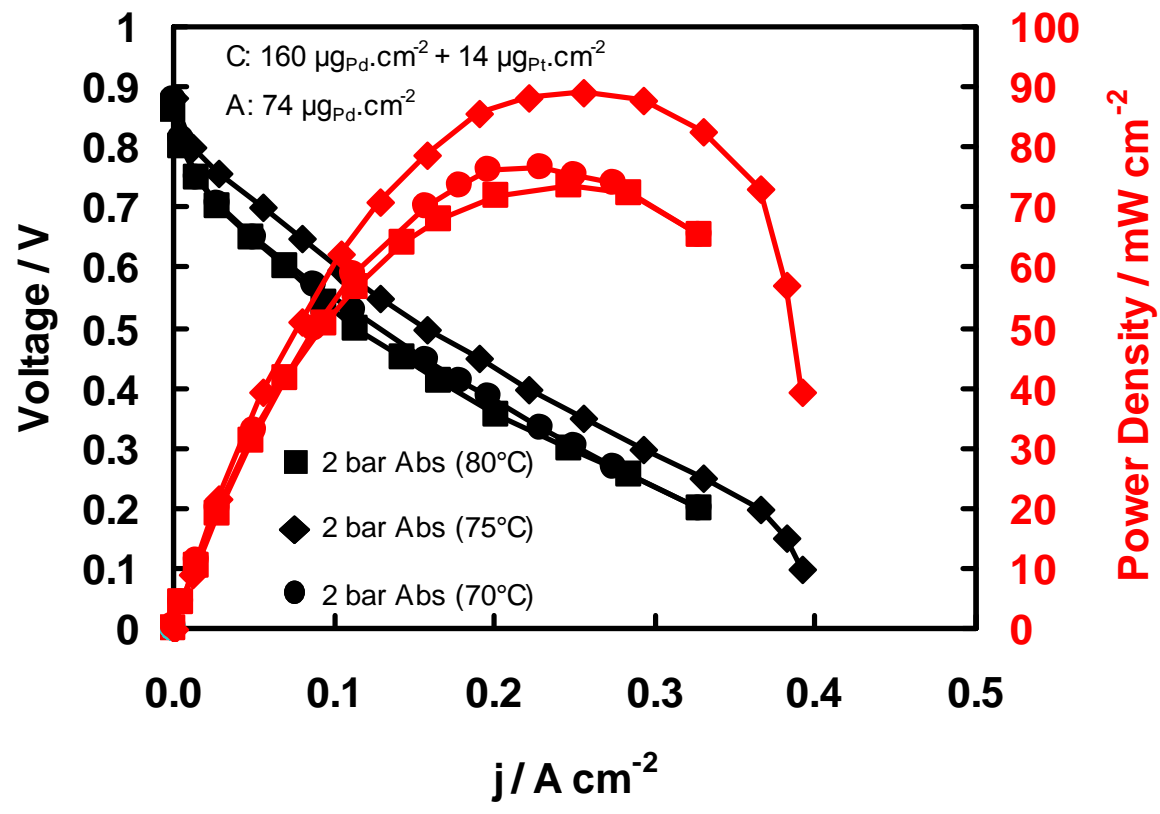

Fig. 3 
MEA-B

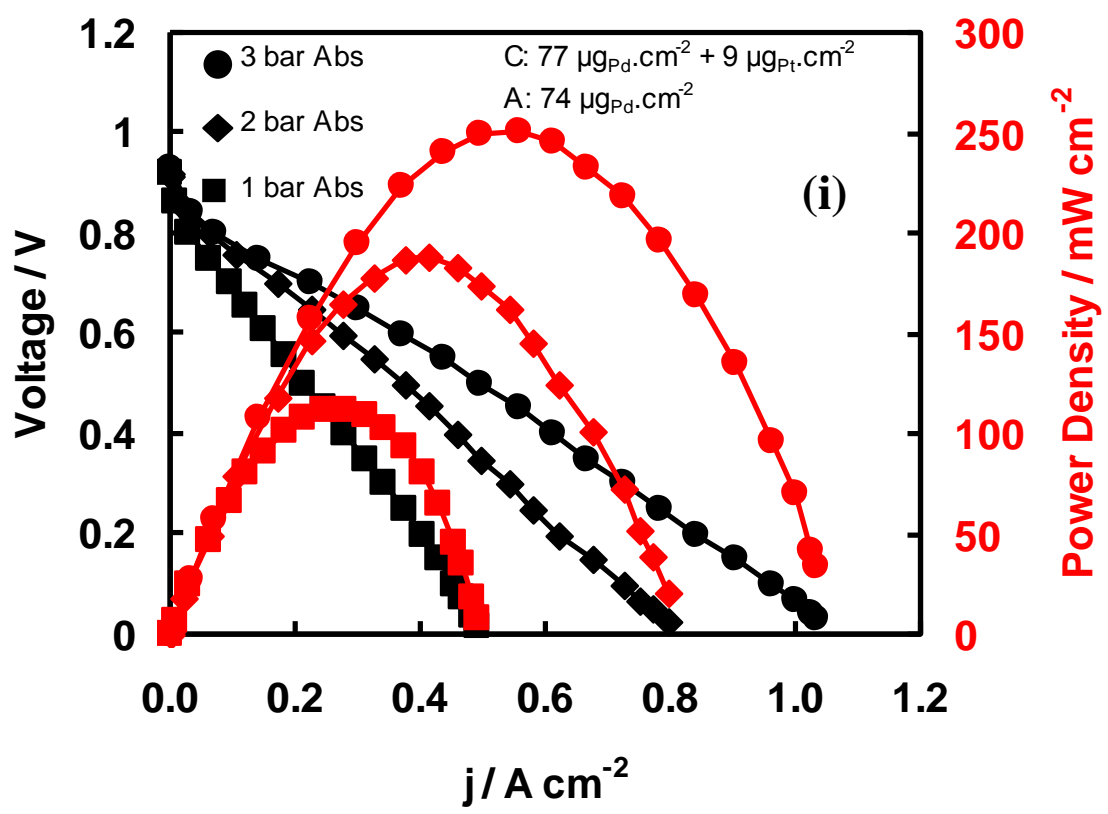

MEA-B

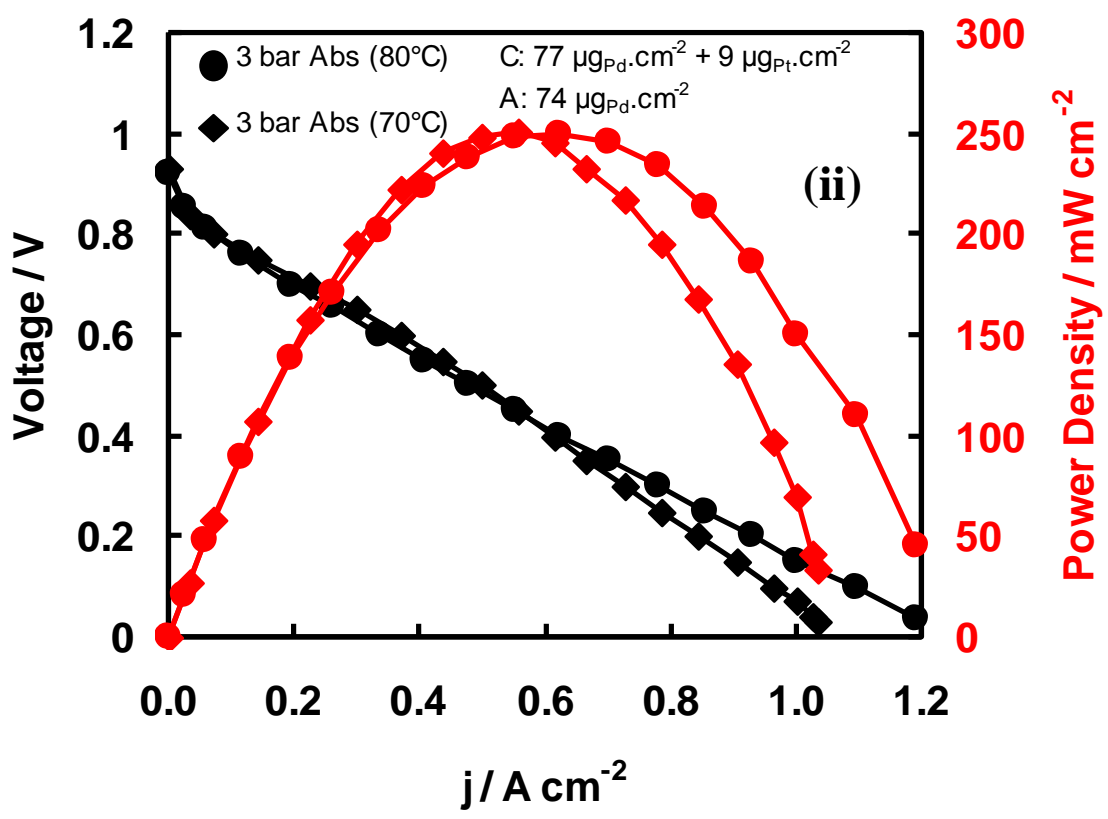

Fig. 4 


\section{MEA-C}

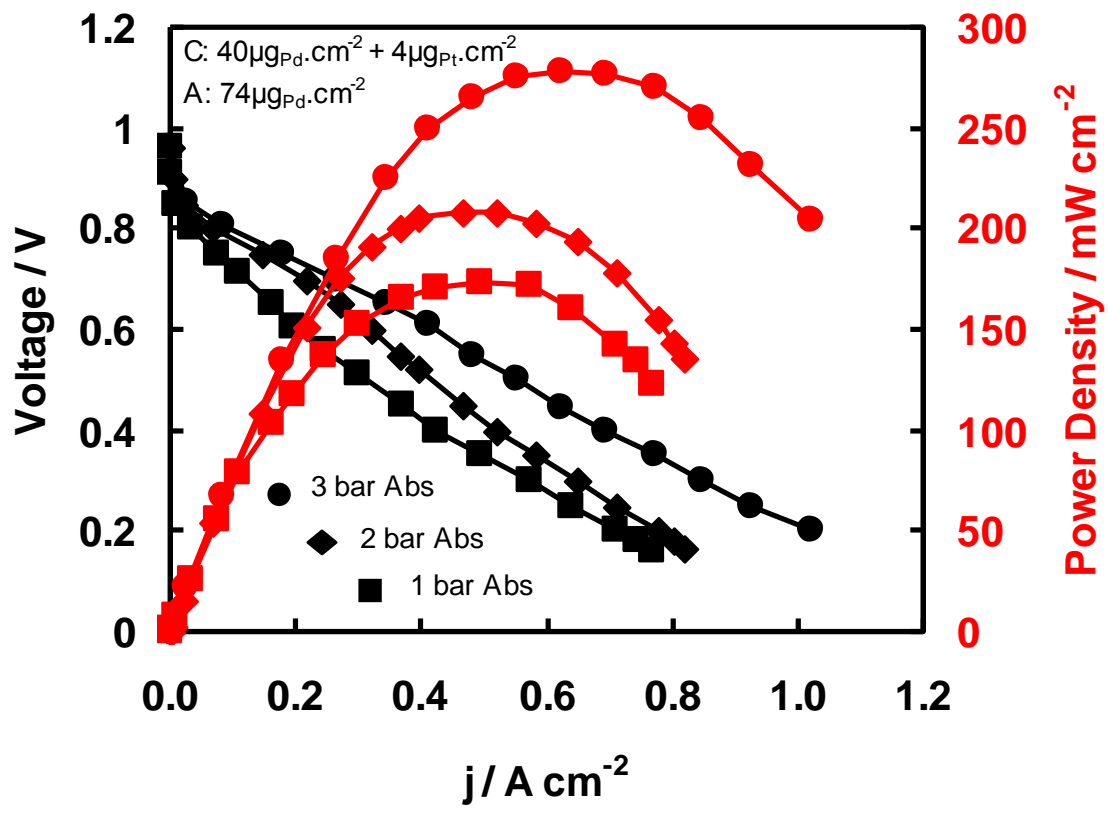

Fig. 5 
MEA-D

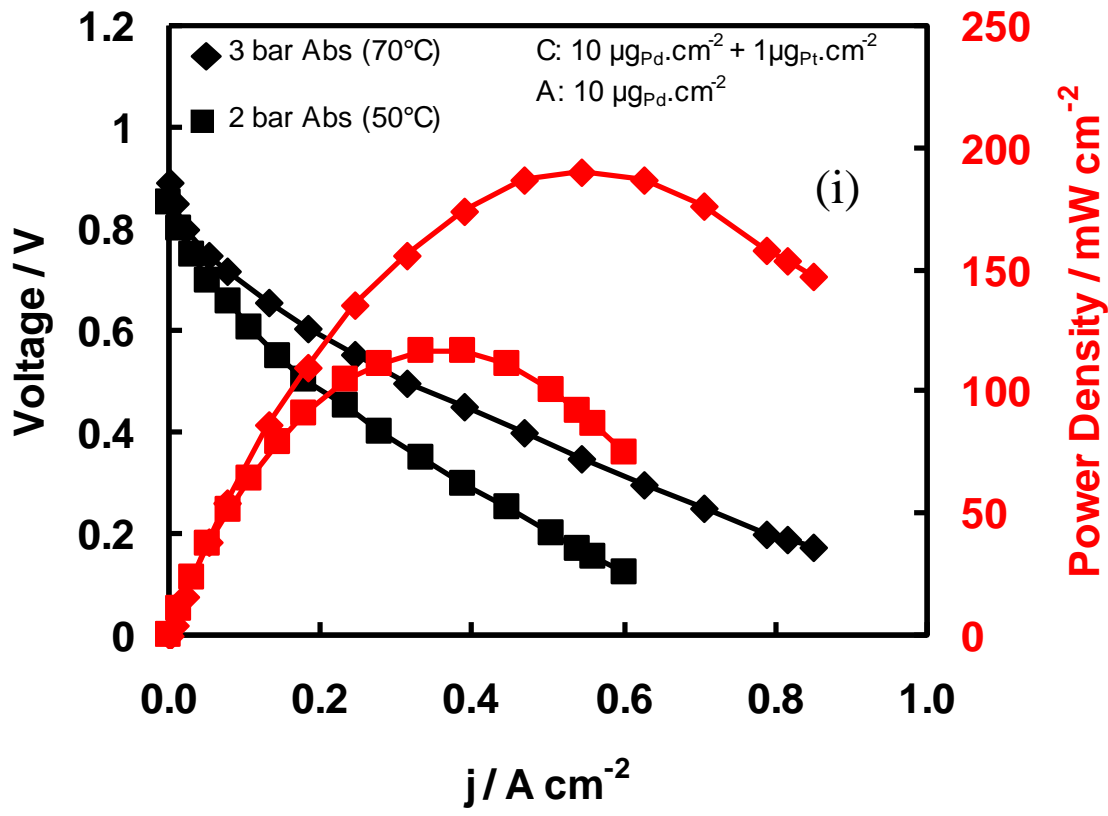

MEA-D

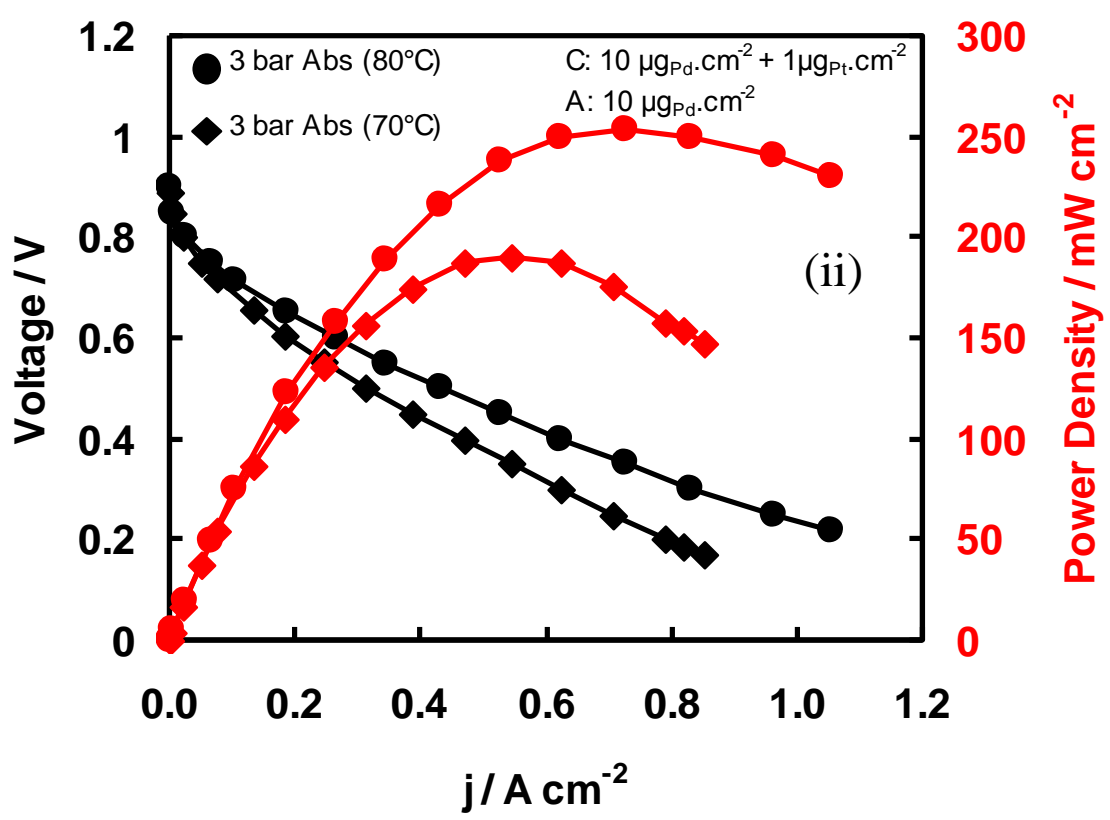

Fig. 6 